\title{
Comparison of the antioxidant potential of antiparkinsonian drugs in different in vitro models
}

\author{
Carine Coneglian de Farias¹, Kamila Landucci Bonifácio ${ }^{1}$, Andressa Keiko Matsumoto² ${ }^{2}$ Luciana \\ Higachi $^{2}$, Rúbia Casagrande ${ }^{1,3}$, Estefânia Gastaldello Moreira ${ }^{1,4}$, Décio Sabbatini Barbosa ${ }^{1,2, *}$
}

\begin{abstract}
${ }^{1}$ Graduation Program in Health Sciences, State University of Londrina, Londrina, Paraná, Brazil, ${ }^{2}$ Department of Pathology, Clinical and Toxicological Analysis, State University of Londrina, Paraná, Brazil, ${ }^{3}$ Department of Pharmaceutical Sciences, State University of Londrina, Paraná, Brazil, ${ }^{4}$ Department of Physiological Sciences, State University of Londrina, Paraná, Brazil
\end{abstract}

\begin{abstract}
Parkinson's disease (PD) is characterized by progressive degeneration of dopaminergic neurons in the substantia nigra pars compacta. Furthermore, oxidative stress plays a role in PD, causing or contributing to the neurodegenerative process. Currently PD has only symptomatic treatment and still nothing can be done to stop the degenerative process of the disease. This study aimed to comparatively evaluate the antioxidant capacity of pramipexole, selegeline and amantadine in different in vitro studies and to offer possible explanations on the molecular antioxidant mechanisms of these drugs. In vitro, the antioxidant capacity of the drugs was assessed by the ability of antiparkinsonian drugs to decrease or scavenge ROS in the neutrophil respiratory burst, ability of antiparkinsonian drugs to donate hydrogen and stabilize the free radical 2,2-diphenyl-1-picryl-hydrazyl (DPPH•), to scavenge 2,2'-azino-di-(3ethylbenzthiazoline-6-sulphonic acid $\left(\mathrm{ABTS}^{+}\right)$and evaluation of the ferric reducing antioxidant power (FRAP). This study demonstrated that both pramipexole and selegiline, but not amantadine, have antioxidant effects in vitro by scavenging superoxide anion on the respiratory burst, donating electron in the $\mathrm{ABTS}^{+}$assay and presenting ferric reduction antioxidant power. This chemical structure-related antioxidant capacity suggests a possible neuroprotective mechanism of these drugs beyond their already recognized mechanism of action.
\end{abstract}

Uniterms: Parkinson's disease. Oxidative stress. Antiparkinsonian drugs/in vitro studies. Antioxidants.

A doença de Parkinson (DP) é caracterizada pela degeneração progressiva dos neurônios dopaminérgicos na substância negra pars compacta. Além disso, o estresse oxidativo, presente nesta doença, causa ou contribui para o processo neurodegenerativo. Atualmente, a DP tem apenas tratamento sintomático e ainda nada pode ser feito para interromper o processo degenerativo. Este estudo teve como objetivo avaliar, comparativamente, a capacidade antioxidante do pramipexol, selegilina e amantadina em diferentes testes in vitro e oferecer possíveis explicações sobre os mecanismos moleculares antioxidantes destes fármacos. Avaliou-se a atividade antioxidante dos fármacos através da capacidade em diminuir ou sequestrar espécies reativas de oxigênio no burst respiratório, da capacidade em doar hidrogênio e estabilizar o radical livre 2,2-difenil-1-picril-hidrazil (DPPH•), de remover o radical 2,2'-azino-di-(3-etilbenzotiazolina-6-sulfônico $\left(\mathrm{ABTS}^{+}\right)$e da verificação do poder redutor/antioxidante do ferro (FRAP). Este estudo demonstrou que tanto o pramipexol como a selegilina, mas não a amantadina, possuem efeitos antioxidantes in vitro por eliminar o ânion superóxido no burst respiratório, doar elétrons no método ABTS e apresentar poder redutor sobre o ferro (FRAP). Essa capacidade antioxidante pode estar relacionada com a estrutura química desses medicamentos, sugerindo possíveis mecanismos neuroprotetores destes fármacos além de seus mecanismos de ação já conhecidos.

Unitermos: Doença de Parkinson. Estresse oxidativo. Fámacos antiparkinsonianos/testes in vitro. Antioxidantes.

\footnotetext{
*Correspondence: Décio S. Barbosa. Departamento de Patologia, Análises Clínicas e Toxicológicas, Centro de Ciências da Saúde, Universidade Estadual de Londrina. Av. Robert Koch, 60. Vila Operária, 86038-440 - Londrina - PR, Brasil. E-mail: sabatini@uel.br
} 


\section{INTRODUCTION}

Parkinson disease (PD) is the second most prevalent neurodegenerative disorder, affecting 1 to $2 \%$ of the population above 65 years of age and, approximately, $4 \%$ of individuals above 85 years (Perfeito, Oliveira, Rego, 2012). The clinical symptoms of PD manifest as the loss of initiation and control of movement, which appear after a substantial loss of dopaminergic neurons (50-60\%) in the substantia nigra pars compacta (SNpc). As a consequence of this cell loss, dopamine in striatum is depleted by 70-80\% (Datla et al., 2007; Mercado, Valde, Hetz, 2013).

The pharmacological treatment of PD has not changed substantially in the past 30 years and dopamimetic therapy is the gold standard. L-dopa and dopaminergic agonists are the main drugs used but a series of enzyme inhibitors, (peripheral decarboxylase inhibitors, catecholO-methyl transferase inhibitors, and monoamine oxidase-B inhibitors, MAO-B) also support dopamimetic therapy (Dexter, Jenner, 2013; Nolan, Sullivan, Toulouse, 2013; Obeso et al., 2010).

The cause of nigral cell death in PD remains unclear, yet several hypotheses have emerged in the scientific literature. The "oxidative stress hypothesis" postulates that a disruption in the balance between antioxidant molecules and reactive oxygen (ROS) and reactive nitrogen species (RNS) leads to oxidative damage of cellular macromolecules and, consequently, to cell death. This hypothesis is based on the fact that the oxidative metabolism of dopamine generates hydrogen peroxide $\left(\mathrm{H}_{2} \mathrm{O}_{2}\right)$ and others ROS, exposing dopaminergic neurons of the SNpc to chronic oxidative stress (Drechsel, Patel, 2008; Liddell et al., 2013). Oxidative stress is evidenced in PD by the increased lipid peroxidation and DNA damage in the substantia nigra and increased encephalic protein oxidation (Surendran, Rajasankar, 2010).

Pramipexole is a synthetic aminobenzothiazole derivative with selective agonistic activity on $\mathrm{D}_{2}$ and $\mathrm{D}_{3}$ receptors. Selegiline is a MAO-B inhibitor, reducing dopamine catabolism at nerve terminals in the basal ganglia. Amantadine is a synthetic tricyclic amine that belongs to the class of aminoadamantanes (Deleu, Northway, Hanssens, 2002). The mechanism of action of amantadine probably involves enhancement of dopaminergic transmission; a mild antimuscarinic activity and a noncompetitive antagonism of the NMDA ( $N$-methyl D-aspartate) receptor (Boll, Zubeldia, Rios, 2011). Even though the mechanisms by which antiparkinsonian drugs increase dopaminergic or decrease cholinergic neurotransmissions are well understood, the literature misses information regarding mechanisms involved in a possible intrinsic antioxidant activity that the antiparkinsonian drugs might have that could, consequently, collaborate to their therapeutical efficacy. This study aimed to comparatively evaluate the antioxidant capacity of three antiparkinsonian drugs (pramipexole, selegeline and amantadine) that can cross the hematoencephalic barrier in different in vitro studies and to offer possible explanations on the molecular antioxidant mechanisms of these drugs.

\section{MATERIAL AND METHODS}

\section{Chemicals}

The drugs used were: amantadine hydrochloride (Mantidan $^{\mathrm{TM}}$, Eurofarma, Brazil), selegiline hydrochloride (Jumexil $^{\mathrm{TM}}$, Chiesi, Brazil), pramipexole dihydrochloride (Sifrol ${ }^{\mathrm{TM}}$, Boehringer-Ingelheim, Brazil). The drugs were macerated and dissolved in dimethylsulfoxide (DMSO: Synth, Brazil). The reagents used for the assays were: luminol (Acros, USA) and phorbolmyristate acetate (PMA), histopaque, 2,2'-azinobis(3-ethylbenzothiazoline6-sulfonic acid) (ABTS), 2,2-diphenyl-1-picrylhydrazyl (DPPH'), 2,4,6-tris(2-pyridyl)-s-triazine (TPTZ), trolox, all from Sigma-Aldrich, USA. All other reagents were of the highest grade available commercially.

\section{Antioxidant activity}

\section{ROS production by neutrophils (respiratory burst)}

ROS production by neutrophils was evaluted by chemiluminescence according to an adaptation of the method described by Freitas et al. (2008) and Huber, Krötz-fahning, Hock (2006) in a multilabel plate reader (Victor X-3, PerkinElmer ${ }^{\mathrm{TM}}$, USA). Human neutrophils were isolated from whole blood through gradient density centrifugation. Neutrophil burst was induced by PMA in the presence of $10^{-4} \mathrm{M}$ of pramipexole, selegiline, amantadine or PBS (control group). Even though DMSO was used to dissolve the test drugs it does not influence respiratory burst as demonstrated in pilot experiments conducted in our laboratory (data not show). The reaction medium in each well was composed by $200 \mu$ L neutrophils $\left(2.5 \times 10^{6}\right.$ cells $\left./ \mathrm{mL}\right), 50 \mu \mathrm{L}$ of luminol $20 \mathrm{mM}, 10 \mu \mathrm{L}$ of the solutions of the test drugs and $50 \mu \mathrm{L}$ of PMA $5 \mathrm{mM}$. After fast homogenization, reading (response range between $300-620 \mathrm{~nm}$ ) was conducted for $60 \mathrm{~min}$ (one $\mathrm{read} / \mathrm{min}$ ) under a temperature of $30 \pm 1^{\circ} \mathrm{C}$. Results are expressed as count per minute (c.p.m.). Each experimental group was composed by at least 14 replicates. For statistical analysis, the peak value of each curve was used, independently of the time it occurred. 


\section{Reduction of free radical DPPH}

The measurement of free radical scavenging was conducted according to Blois, (1958), with some modifications. Antiparkinsonian drugs were added to the reaction mixture containing $1 \mathrm{~mL} 0.1 \mathrm{M}$ acetate buffer (pH 5.5), $1 \mathrm{~mL}$ of ethanol and $0.5 \mathrm{~mL}$ of ethanolic solution of $\mathrm{DPPH}^{\cdot} 250 \mathrm{M}$. The drugs concentrations in the reaction were $0.002-0.05 \mathrm{mg} / \mathrm{mL}$ of pramipexole, $0.015-0.25 \mathrm{mg} / \mathrm{mL}$ of selegiline and $0.311-5.4 \mathrm{mg} / \mathrm{mL}$ of amantadine. The reduction of DPPH' radical was determined by the change in absorbance measured at $517 \mathrm{~nm}$. The suppression of the colored radical results in absorbance decrease. The positive control was prepared in the absence of the test drugs in order to determine the maximum odd electrons of $\mathrm{DPPH}^{\circ}$, which was considered $100 \%$ of free radicals in the solution and used to calculate the hydrogendonating ability (\%) of the drugs evaluated. The blank was prepared from the reaction mixture without $\mathrm{DPPH}^{\circ}$ solution. Samples were analyzed in triplicate. The results were expressed as percentage of activity by the following equation:

Equation I: \% of activity $=[1-$ (sample absorbance) control absorbance)] x 100.

\section{ABTS free radical scavenging assay}

The ability to scavenge the $\mathrm{ABTS}^{+}$free radical was carried out according to Sánchez-Gonzáles, JiménezEscrig, Saura-Calixto (2005) with some modifications. $\mathrm{ABTS}^{+}$solution was obtained after the reaction of $7 \mathrm{mM}$ ABTS with $2.45 \mathrm{mM}$ potassium persulphate. This solution was diluted in phosphate buffer $(\mathrm{pH} 7.4,0.1 \mathrm{M})$ until it reached an absorbance of 0.7 to 0.8 at $730 \mathrm{~nm}$. Different concentrations of pramipexole $0.001-0.03 \mathrm{mg} / \mathrm{mL}$, selegiline $0.015-0.225 \mathrm{mg} / \mathrm{mL}$ and amantadine $0.311-5.4 \mathrm{mg} / \mathrm{mL}$ were evaluated. The suppression of the colored radical on the medium was monitored through the decrease in absorbance. The positive control was prepared in the absence of the test drugs and was considered $100 \%$ of free radicals in the solution, which was used to calculate the scavenging ability of the drugs. The blank was prepared with a solution of potassium persulfate diluted in phosphate buffer. Samples were performed in triplicate and the ability of scavenging $\mathrm{ABTS}^{+}$was calculated by equation I.

\section{Ferric reducing antioxidant power (FRAP test)}

FRAP was evaluated according to SánchezGonzáles, Jiménez-Escrig, Saura-Calixto (2005) with some modifications. In this assay, antioxidants added to medium reduce the $\mathrm{Fe}^{+3} \mathrm{TPTZ}$ complex to form a blue- colored $\mathrm{Fe}^{+2} \mathrm{TPTZ}$ complex, which results in an increase in the absorbance.

FRAP reagent was prepared with $2.5 \mathrm{~mL}$ of the solution of TPTZ $(10 \mathrm{mM})$ in HCI $(40 \mathrm{mM}), 2.5 \mathrm{~mL}$ $\mathrm{FeCl}_{3} .\left(6 \mathrm{H}_{2} \mathrm{O}\right)$ solution and $25 \mathrm{~mL}$ of acetate buffer $(\mathrm{pH} 3.6,0.3 \mathrm{Mm})$. The solution was incubated at $37^{\circ} \mathrm{C}$ for $30 \mathrm{~min}$. For the assay, $900 \mu \mathrm{L}$ of FRAP reagent were added to $90 \mu \mathrm{L}$ of water and $10 \mu \mathrm{L}$ of trolox standard and $150 \mu \mathrm{L}$ of pramipexole $(0.164 \mathrm{mg} / \mathrm{mL})$ or $100 \mu \mathrm{L}$ of selegiline $(0.573 \mathrm{mg} / \mathrm{mL})$ or $180 \mu \mathrm{L}$ of amantadine $(19.23 \mathrm{mg} / \mathrm{mL})$ in the reaction medium. After incubation at $37^{\circ} \mathrm{C}$ for 30 minutes, measurements were obtained in a spectrophotometer at $595 \mathrm{~nm}$. An analytical curve with different concentrations of trolox $(4.0-20.0 \mu \mathrm{M})$ was used for subsequent calculation of results in $\mu \mathrm{mol} / \mathrm{L}$ trolox equivalent $\mathrm{mg} / \mathrm{mL}$ of the drugs. The positive control was prepared in the absence of the test drugs. The blank was prepared with a solution of FRAP reagent and water. Samples were performed in triplicate.

\section{STATISTICAL ANALYSIS}

Initially, an exploratory analysis was conducted with data from the respiratory burst in order to evaluate Gaussian distribution (Shapiro-Wilk test) and homogeneity of variance (Levene's test). In the absence of normal distribution and homogeneity of variance, data were analyzed through the non-parametric test of KruskalWallis complemented with Dunn. Results are presented as median, minimum ( $\mathrm{min}$ ) and maximum (max) values considering the peak value of each curve.

The in vitro concentration of pramipexole, selegiline and amantadine that caused $50 \%$ of DPPH and ABTS scavenging was considered the mean inhibitory concentration (IC50). The IC50 was determined by GraphPadPrism ${ }^{\circledR}$ software, version 3.02, using hyperbolic curve (one site binding hyperbole). On the FRAP the results obtained with the test-drugs were compared to trolox curve. Antioxidant activity results are presented as means \pm standard error mean (SEM).

Results were considered statistically significant if $P<0.05$.

\section{RESULTS}

\section{Pramipexole and selegiline decrease ROS production by neutrophils}

Figure 1A presents the chemiluminescence produced by PMA-stimulated neutrophils in the absence (Control) or presence of $10^{-4} \mathrm{M}$ pramipexole, selegeline and 
amantadine. Each curve was plotted with the median of at least 14 replicates. Kruskall-Wallis indicated a significant difference in the peak values of the kinetic curves $(\mathrm{KW}=28.9, \mathrm{p}<0.0001)$. Dunn's test revealed that the peak values obtained with both pramipexole and selegeline were significantly lower than control (Figure 1B). Amantadine lacked antioxidant effect. As observed in Figure 1B, the control neutrophils have shown median c.p.m. of 87859 (76463 to 105561 ), whereas the values for pramipexole, selegeline and amantadine were, respectively: 24364 (23208 to 26404), 57418 (53884 to $62901)$ and 78418 (74934 to 84717).

\section{Free radical scavenging assays}

The ability of pramipexole, selegiline and amantadine to scavenge $\mathrm{ABTS}^{+}$, $\mathrm{DPPH}^{\circ}$ and FRAP was evaluated.

In the $\mathrm{ABTS}^{+}$assay, both pramipexole and selegiline scavenged the positively charged $\mathrm{ABTS}^{+}$radical in a concentration-dependent manner (Figure 2A and 2B). Pramipexole assay resulted in a linearity of $\mathrm{R}^{2} 0.9749$ between 0.001 to $0.03 \mathrm{mg} / \mathrm{mL}$. Maximum activity was found to be $99 \%$ at the concentration of $0.03 \mathrm{mg} / \mathrm{mL}$ and IC50 was $0.002 \mathrm{mg} / \mathrm{mL}$. Selegiline assay showed a linearity of $\mathrm{R}^{2} 0.9934$ between 0.015 and $0.225 \mathrm{mg} / \mathrm{mL}$. Maximum activity was $54 \%$ at the concentration of $0.225 \mathrm{mg} / \mathrm{mL}$ and IC50 was $0.191 \mathrm{mg} / \mathrm{mL}$ (Figure 2B). Amantadine did not present scavenging activity and the concentration-response curve parameters could not be calculated.

In the $\mathrm{DPPH}^{\cdot}$ assay any of the drugs presented scavenging activity (data not shown).

On FRAP assay, pramipexole $(1 \mathrm{mg} / \mathrm{mL})$ reducing power was $11.8 \pm 0.9 \mu \mathrm{mol} / \mathrm{L}$ trolox equivalent $(\mathrm{n}=3)$ and

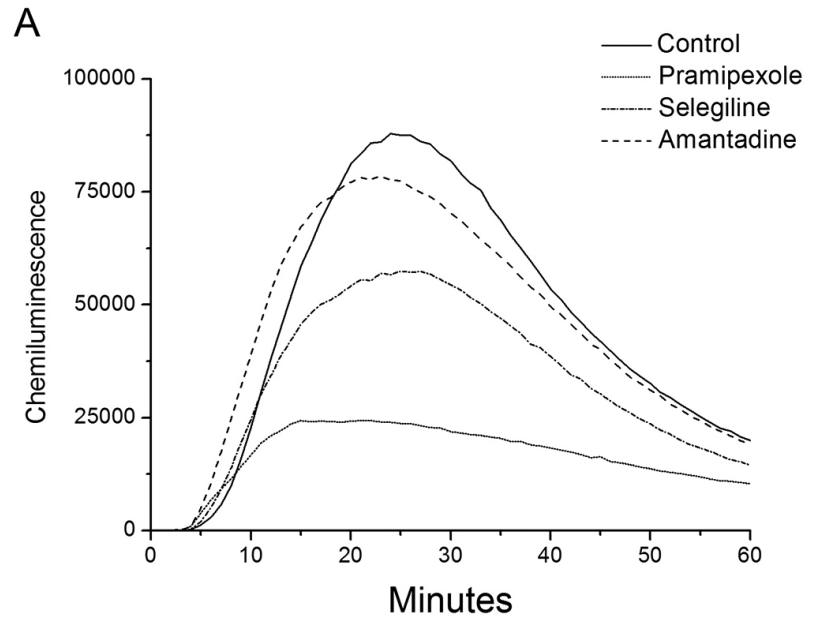

B

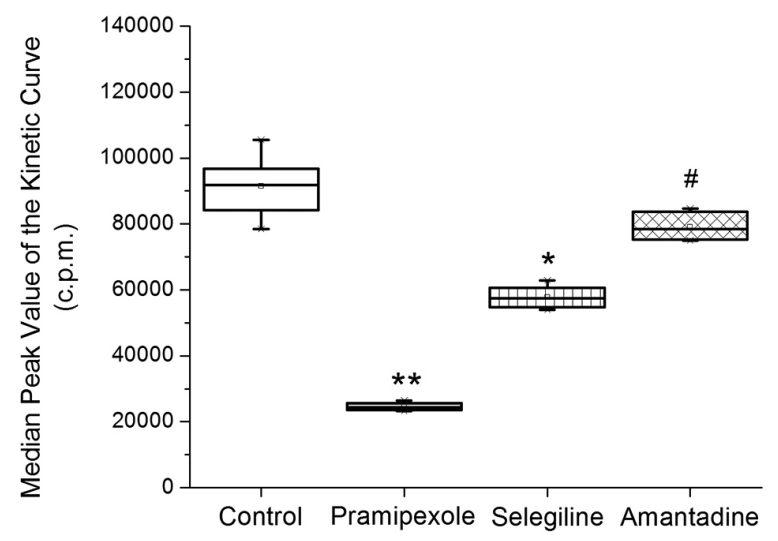

FIGURE 1 - Effect of antiparkinsonian drugs $\left(10^{-4} \mathrm{M}\right)$ on the activation of human neutrophils by PMA. Each group was composed by at least 14 replicates. A. Kinetic curves obtained each minute for 60 minutes. B. Box plot of the peak values on the kinetic curves. Data were analyzed by Kruskal-Wallis complemented with Dunn's test. * $\mathrm{p}<0.01$ compared to control; $* * \mathrm{p}<0.001$ compared to control. c.p.m. $=$ count per minute.
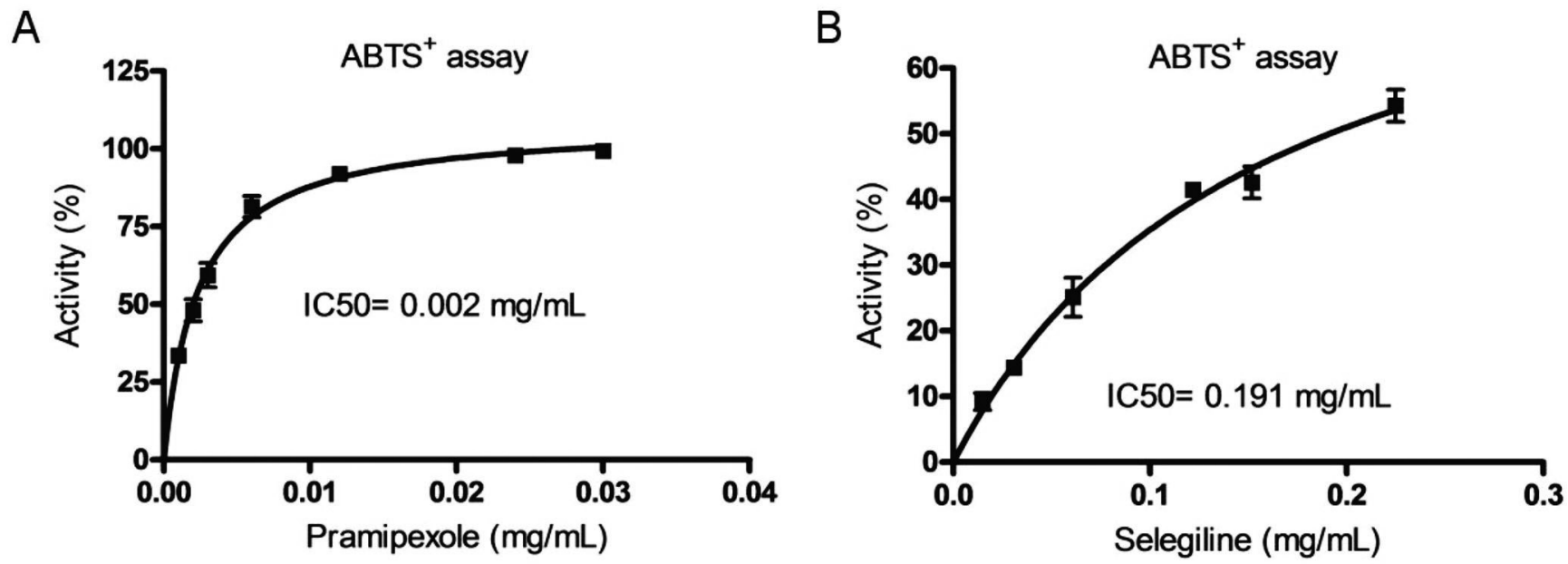

FIGURE 2 -Free radical scavenging activity of pramipexole (A) and selegiline (B) in the $\mathrm{ABTS}^{+}$assay. Data are means \pm standard error mean (SEM) of triplicate values and are presented as percentage of inhibition relative to control. 
selegiline $(1 \mathrm{mg} / \mathrm{mL})$ one was $8.9 \pm 0.96 \mu \mathrm{mol} / \mathrm{L}$ trolox equivalent $(\mathrm{n}=3)$, demonstrating that pramipexole presents 1.32-fold greater activity than selegiline. As observed in the other tests, amantadine lacked antioxidant response in this assay.

\section{DISCUSSION}

Over the past few decades a large volume of data generated from clinical studies, autopsies and in vitro and in vivo experimental models have suggested that nitrosative and oxidative stress play an important role in neurodegeneration of the substantia nigra associated with PD. ROS/RNS lead to molecular damage (lipid and protein oxidation, DNA damage) that can disrupt biological functions and ultimately induce neuronal death (Danielson, Andersen, 2008; Perfeito, Oliveira, Rego, 2012).

To our knowledge this is the first time that a correlation between the possible antioxidant effects of pramipexole and selegiline with their chemical structure has been investigated. This study demonstrated that both pramipexole and selegiline, but not amantadine, have antioxidant effects in vitro by scavenging superoxide anion $\left(\mathrm{O}_{2}{ }^{-}\right)$on the respiratory burst, donating electron in the $\mathrm{ABTS}^{+}$assay and presenting ferric reduction antioxidant power. This antioxidant capacity suggests a possible neuroprotective mechanism of these drugs beyond their already recognized mechanism of antiparkinsonian effect.

Pramipexole and selegiline produced positive effects scavenging $\mathrm{ABTS}^{+}$radical and presenting ferric reduction antioxidant power but lacked effect towards DPPH ${ }^{\circ}$ radical. The antioxidant activity of these drugs may be due to reducing power related to their chemical structure.

Pramipexole is a dopaminergic agonist that consists of a fused bicyclic tetrahydrobenzothiazole (Figure 3) (Baumann et al., 2011). The antioxidant activity observed in the respiratory burst could have resulted from the neutralization of the $\mathrm{O}_{2}{ }^{--}$by the release of one proton $\left(\mathrm{H}^{+}\right)$from the amino group $\left(\mathrm{NH}_{2}\right)$ of pramipexole. After the donation, the radical can resonates with the thiazole ring whereas the neutralization of the superoxide radical would allow it to dissociate into $\mathrm{H}_{2} \mathrm{O}$ and $\mathrm{O}_{2}$. Moreover, pramipexole molecule also presents two secondary amine groups, which can donate the pair of electrons to neutralize ROS and induce the antioxidant activity observed in the $\mathrm{ABTS}^{+}$and FRAP assays.

Our results corroborate studies from the literature that describe antioxidant activity for pramipexole both in vitro (Cassarino et al., 1998; Ferger, Teismann, Mierau, 2000; Gu et al., 2004) and in vivo (Cassarino et al., 1998;
Ferger, Teismann, Mierau, 2000; Le et al., 2000). In vitro, pramipexole reduced the levels of methylpyridinium ion $\left(\mathrm{MPP}^{+}\right)$-produced oxygen radicals in SH-SY5Y cells and it was also able to reduce Fenton reactionderived hydroxyl radical (Cassarino et al., 1998; Ferger, Teismann, Mierau, 2000). In vivo, pramipexole inhibited ROS production via decreased turnover of dopamine metabolism mediated by its action on dopaminergic autoreceptors. In addition, it also presented a direct scavenging activity and stimulated cellular glutathione peroxidase and catalase (Le et al., 2000) and reduced the levels of 6-hydroxydopamine-induced hydroxyl radical in the striatum (Ferger, Teismann, Mierau, 2000). In addition, it was demonstrated that pramipexole inhibited MPP + ioninduced lipid peroxidation in C57BL/6 mice (Zou et al., 2000). Taken together, data seem to support an antioxidant activity for pramipexole, which could result from intrinsic characteristics of its molecule.

Selegiline is a selective irreversible inhibitor of MAO-B, the enzyme responsible for the oxidative metabolism of dopamine and which activity increases in the brain during aging and neurodegeneration. The inhibition of MAO-B can prevent ROS formation from dopamine metabolism. Some studies have described a neuroprotective effect of this drug independent of its inhibitory action on MAO (Boll, Zubeldia, Rios, 2011; Follmer, 2013; Singh, Pillay, Choonara, 2007). Takahata et al. (2006) described that selegiline can decrease oxidative stress in nigrostriatum by augmenting the antioxidant capacity, i.e., increasing the activity of antioxidant enzymes (superoxide dismutase and catalase) and the level of glutathione in specific brain regions. Goverdhan, Sravanthi, Mamatha (2012) demonstrated that selegiline inhibited lipid peroxidation and increased endogenous antioxidant enzymes in brain samples of an Alzheimer disease mouse model. The results obtained in the present work suggest an intrinsic antioxidant ability of the selegiline molecule, which could be attributable to the propargylamine group (Figure 3). This group is formed by propargyl, containing the unit acetylene (alkyne), as well as by a tertiary amine. It is hypothesized that selegeline was able to reduce the respiratory burst through the release of a proton $\left(\mathrm{H}^{+}\right)$from the acetylenic unit that neutralized the $\mathrm{O} 2{ }^{*}$. Moreover, the tertiary amine group could also have shared a pair of electrons and neutralized ROS, as observed in three out of four assays employed in this study. It is noteworthy that even though selegeline presented an intrinsic antioxidant activity, it was less effective than the one observed with pramipexole. Probably, the selegiline radical produced after the proton release is less stable compared to the pramipexole that 


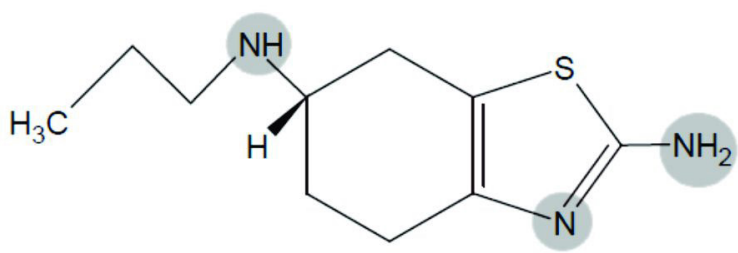

Pramipexole

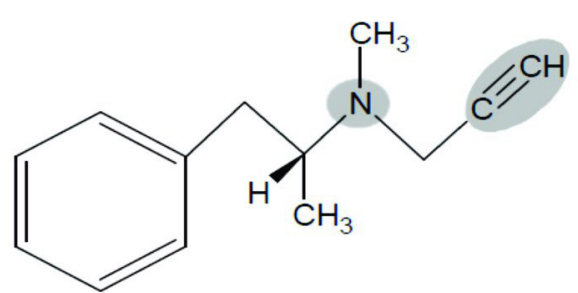

Selegiline

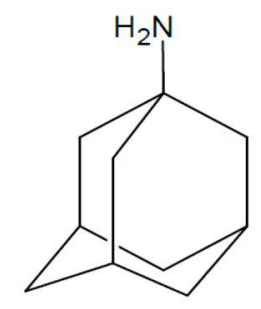

Amantadine

FIGURE 3 -Chemical structure of antiparkinsonian drugs. The structural characteristics of pramipexole, selegiline, but not amantadine, can define antioxidant action of these drugs. Highlighted areas would allow this antioxidant activity.

is stabilized by its functional groups. Hall et al. (1996) evaluated the oxidative degradation of pramipexole in an electrochemical cell. Pramipexole is readily susceptible for oxidation (i.e., ability to lose or possibly donate an electron) qualifying it as having antioxidant capability. However, this property has not been demonstrated for selegiline.

Amantadine lacked in vitro antioxidant activity in all the assays conducted in this study even though this drug also presents an amino $\left(\mathrm{NH}_{2}\right)$ group (Figure 3). Our results support the importance of a conjugated system to stabilize the load (like pramipexole) because isolated groups (as observed in amantadine) do not result in antioxidant activity. Supporting the present results, Lupp et al. (1998) reported that amantadine presented the lowest in vitro antioxidant activity compared to others non-competitive $N$-methyl-D-aspartate (NMDA)-receptor antagonists.

Interestingly, pramipexole and selegiline failed to stabilize the radical DPPH'. A possible explanation for this lack of effect would be the low reactivity of this radical as well as steric hindrance caused by its bulky molecular structure (Prior, Wu, Schaich, 2005).

\section{CONCLUSIONS}

Both pramipexole and selegiline have shown in vitro antioxidant activity either in $\mathrm{ABTS}^{+}$and FRAP assays as well as in respiratory burst assay, which is a more complex model. Although some studies have already pointed into this direction, the literature was lacking a comparative study among antiparkinsonian drugs as well as a discussion on the hypotheses that could explain the antioxidant mechanisms of these drugs. If the antioxidant activity of pramipexole and selegeline offers neuroprotection and contributes effectively in delaying PD progression is an open question that remains to be answered.

\section{REFERENCES}

BAUMANN, M.; BAXENDALE, I.R.; LEY, S.V.; NIKBIN, $\mathrm{N}$. An overview of the key routes to the best selling 5-membered ring heterocyclic pharmaceuticals. J. Org. Chem., v.7, p.442-495, 2011.

BLOIS, M.S. Antioxidant determinations by the use of a stable free radical. Nature, v.181, p.1199-1200, 1958.

BOLL, M.C.; ZUBELDIA, M.A.; RIOS, C. Medical management of Parkinson's disease: focus on neuroprotection. Curr. Neuropharmacol., v.9, n.2, p.350-359, 2011.

CASSARINO, D.S.; FALL, C.P.; SMITH, T.S.; BENNETT, J.J.P. Pramipexole reduces reactive oxygen species production in vivo and in vitro and inhibits the mitochondrial permeability transition produced by the parkinsonian neurotoxin methylpyridinium ion. J. Neurochem., v.71, p.295-301, 1998.

DANIELSON, S.R.; ANDERSEN, J.K. Oxidative and nitrative protein modifications in Parkinson's disease. Free Radic. Biol. Med., v.44, p.1787-1794, 2008.

DATLA, K.P.; ZBARSKY, V.; RAI, D.; PARKAR, S.; OSAKABE, N.; ARUOMA, O.I.; DEXTER, D.T. Shortterm supplementation with plant extracts rich in flavonoids protect nigrostriatal dopaminergic neurons in a rat model of Parkinson's disease. J. Am. Coll. Nutr., v.26, p.341-349, 2007.

DELEU, D.; NORTHWAY, M.G.; HANSSENS, Y. Clinical pharmacokinetic and pharmacodynamic properties of drugs used in the treatment of Parkinson's disease. Clin. Pharmacokinet., v.41, p.261-309, 2002. 
DEXTER, D.T.; JENNER, P. Parkinson disease: from pathology to molecular disease mechanisms. Free Radic. Biol. Med., v.63, p.132-144, 2013.

DRECHSEL, D.A.; PATEL, M. Role of reactive oxygen species in the neurotoxicity of environmental agents implicated in Parkinson's disease. Free Radic. Biol. Med., v.44, p.18731886, 2008.

FERGER, B.; TEISMANN, P.; MIERAU, J. The dopamine agonist pramipexole scavenges hydroxyl free radicals induced by striatal application of 6-hydroxydopamine in rats: an in vivo microdialysis study. Brain Res., v.883, p.216-223, 2000.

FOLLMER, C. Fármacos multifuncionais: monoamina oxidase e $\alpha$-sinucleína como alvos terapêuticos na doença de Parkinson. Quím. Nova, v.36, p.306-313, 2013.

FREITAS, M.; PORTO, G.; LIMA, J.L.; FERNANDES, E. Isolation and activation of human neutrophils in vitro. The importance of the anticoagulant used during blood collection. Clin. Biochem., v.41, n.7-8, p.570-575, 2008.

GOVERDHAN, P.; SRAVANTHI, A.; MAMATHA, T. Neuroprotective effects of Meloxicam and Selegiline in scopolamine-Induced cognitive impairment and oxidative stress. Int. J. Alzheimers Dis., v.2012, p.1-8, 2012.

GU, M.; IRVANI, M.M.; COOPER, J.M.; KING, D.; JENNER, P.; SCHAPIRA, A.H. Pramipexole protects against apoptotic cell death by non-dopaminergic mechanisms. $J$. Neurochem., v.91, n.5, p.1075-1081, 2004.

HALL, E.D.; ANDRUS, P.K.; OOSTVEEN, J.A.; ALTHAUS, J.S.; VONVOIGTLANDER, P.F. Neuroprotective effects of the dopamine D2/D3 agonist pramipexole against postischemic or methamphetamine-induced degeneration of nigrostriatal neurons. Brain Res., v.742, p.80-88, 1996.

HUBER, K.; KRÖTZ-FAHNING, M.; HOCK, B. Respiratory burst as a biomarker for stress response. Protoplasma, v.229, p.221-224, 2006.

LE, W.D.; JANKOVIC, J.; XIE, W.; APPEL, S.H. Neuroprotective effect of L-dopa on dopaminergic neurons is comparable to pramipexol in MPTP-treated animal model of Parkinson's disease: a direct comparison study. $J$. Neurochem., v.107, p.1165-1173, 2000.
LIDDELL, J.R.; OBANDO, D.; LIU, J.; GANIO, G.; VOLITAKIS, I.; MOK, S.; CROUCH, P.J.; WHITE, A.R.; CODD, R. Lipophilic adamantly or deferasirox based conjugates of desferrioxamine $\mathrm{B}$ have enhanced neuroprotective capacity: implications for Parkinson disease. Free Radic. Biol. Med., v.60, p.147-156, 2013.

LUPP, A.; KERST, S.; KARGE, E.; QUACK, G.; KLINGER, W. Investigation on possible antioxidative properties of the NMDA-receptor antagonists ketamine, memantine, and amantadine in comparison to nicanartine in vitro. Exp. Toxicol. Pathol., v.50, p.501-506, 1998.

MERCADO, G.; VALDE, S.P.; HETZ, C. An ERcentric view of Parkinson's disease. Trends Mol. Med., v.19, p.165-175, 2013.

NOLAN, Y.M.; SULLIVAN, A.M.; TOULOUSE, A. Parkinson's disease in the nuclear age of neuroinflammation. Trends Mol. Med., v.19, p.187-196, 2013.

OBESO, J.A.; RODRIGUEZ-OROZ, M.C.; GOETZ, C.G.; MARIN, C.; KORDOWER, J.H.; RODRIGUEZ, M.; HIRSCH, E.C.; FARRER, M.; SCHAPIRA, A.H.V.; HALLIDAY, G. Missing pieces in the Parkinson's disease puzzle. Nat. Med., v.16, p.653-661, 2010.

PERFEITO, R.; OLIVEIRA, T.C.; REGO, A.C. Revisiting oxidative stress and mitochondrial dysfunction in the pathogenesis of Parkinson disease- resemblance to the effect of amphetamine drugs of abuse. Free Radic. Biol. Med., v.53, p.1791-1806, 2012.

PRIOR, R.L.; WU, X.; SCHAICH, K. Standardized methods for the determination of antioxidant capacity and phenolics in foods and dietary supplements. J. Agric. Food Chem., v.53, p.4290-4302, 2005.

SÁNCHEZ-GONZÁLES, I.; JIMÉNEZ-ESCRIG, A.; SAURACALIXTO, F. In vitro antioxidant activity of coffees brewed using different procedures (Italian, espresso and filter). Food Chem., v.90, p.133-139, 2005.

SINGH, N.; PILLAY, V.; CHOONARA, Y.E. Advances in the treatment of Parkinson's disease. Prog. Neurobiol., v.81, p.29-44, 2007.

SURENDRAN, S.; RAJASANKAR, S. Parkinson's disease: oxidative stress and therapeutic approaches. Neurol. Sci., v.31, p.531-540, 2010. 
TAKAHATA, K.; SHIMAZU, S.; KATSUKI, H.; YONEDA, F.; AKAIKE, A. Effects of selegiline on antioxidant systems in the nigrostriatum in rat. J. Neural. Transm., v.113, p.151$158,2006$.
ZOU, L-L.; XU, J.; JANKOVIC, J.; HE, Y.; APPEL, S.H.; LE, W-D. Pramipexole inhibits lipid peroxidation and reduces injury in the substantia nigra induced by the dopaminergic neurotoxin 1-methyl- 4-phenyl-1,2,3,6-tetrahydropyridine in C57BL/6 mice. Neurosci. Lett., v.281, p.167-170, 2000.

Received for publication on $12^{\text {th }}$ August 2013 Accepted for publication on $08^{\text {th }}$ May 2014 